\title{
THE DETERMINANTS \\ OF OIL DEMAND: EVIDENCE \\ FROM ITALY
}

Hacettepe University

Journal of Economics

and Administrative

Sciences

Vol. 35, Issue 4, 2017,

pp. $31-51$

\author{
Muhammed Şehid GÖRÜŞ \\ Res.Asst., Ankara Yıldırım Beyazıt \\ University \\ Faculty of Political Sciences \\ Department of Economics \\ msgorus@ybu.edu.tr

\section{Önder ÖZGÜR} \\ Res.Asst., Ankara Yıldırım Beyazıt \\ University \\ Faculty of Political Sciences \\ Department of Economics \\ oozgur@ybu.edu.tr
}

A

bstract: The main purpose of this paper is to estimate price and income elasticities of crude oil demand in the Italian economy between 1975 and 2014. The Bound Test is employed as an econometric estimation method. According to Bound Test result, a cointegration relationship has been found between oil consumption, oil prices, and real income. Empirical findings show that the long-run income elasticity and price elasticity of oil demand are statistically insignificant in Italy. In addition, price and income elasticities of oil demand estimated as negative-inelastic and positive-inelastic in the short run, respectively. Thus, crude oil can be defined as a necessity good for Italian consumers over the short term. Also, Error Correction Term (ECT) is estimated to be 1.18. According to ECT, a deviation from the long run equilibrium level of oil demand is corrected about one year later. Italy is an energy dependent country and imports most of it. Since crude oil is necessity, the government should diversify energy sources which are consumed in the entire country and/or undertake policies to increase energy efficiency.

Keywords: Bound test, cointegration, Italy, oil demand. 


\section{PETROL TALEBININ BELİRLEYÍCILERİ: ITTALYA ÖRNEĞİ}

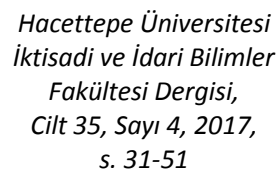

\author{
Muhammed Şehid GÖRÜŞ \\ Arş.Gör., Ankara Yıldırım Beyazıt \\ Üniversitesi \\ Siyasal Bilgiler Fakültesi \\ Ekonomi Bölümü \\ msgorus@ybu.edu.tr

\section{Önder ÖZGÜR} \\ Arş.Gör., Ankara Yıldırım Beyazıt \\ Üniversitesi \\ Siyasal Bilgiler Fakültesi \\ Ekonomi Bölümü \\ oozgur@ybu.edu.tr
}

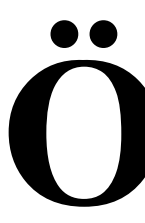

z: Bu çalışmanın temel amacı 1975 ve 2014 dönemi için İtalya ekonomisindeki petrol talebinin fiyat ve gelir esnekliklerini tahmin etmektir. $\mathrm{Bu}$ amaç için Sınır Testi ekonometrik tahmin yöntemi olarak kullanılmıştır. Elde edilen sonuçlara göre, petrol tüketimi, petrol fiyatları ve reel gelir seviyesi arasında bir eşbütünleşme ilişkisi tespit edilmiştir. Ampirik sonuçlara göre, petrol talebinin fiyat ve gelir esneklikleri uzun dönemde istatistiki olarak anlamsızdır. Bunun yanında, kısa dönemde ise fiyat ve gelir esneklikleri sırasıyla negatif-sert ve pozitif-sert olarak tahmin edilmiştir. $\mathrm{Bu}$ yüzden, ham petrol kısa dönemde İtalyan tüketiciler için zorunlu mallar arasında gösterilebilir. Bununla birlikte, Hata Düzeltme Terimi (HDT) -1.18 olarak hesaplanmıştır. HDT'ye göre, petrol talebinin uzun dönem dengesindeki bir sapma yaklaşık bir sene sonra dengeye gelmektedir. İtalya, enerjiye bağımlı bir ülkedir ve tüketiminin çoğunu ithalat yoluyla karşılamaktadır. Ham petrolün zorunlu mallar arasında yer almasından dolayı, İtalyan hükümeti ülkedeki enerji kaynaklarını çeşitlendirmeli ve/veya enerji verimliliğini arttırıcı politikalar üstlenmelidir.

Anahtar Sözcükler: Sinır testi, eşbütünleşme, Italya, petrol talebi. 


\section{INTRODUCTION}

Energy plays a crucial role in the life of people in today's world. Countries must consume energy in every part of their economic activities, and the intensity of energy dependency gradually increases due to relentless technological changes. Countries that aim to increase the welfare of their citizens' needs to achieve economic growth. When it is thought that economic growth is simply an increase in the volume of production level, energy as an input to the manufacturing process becomes one of the most important determinants of economic growth. Therefore, it is a positive relationship between energy consumption and economic growth is expected.

Energy sources can be classified according to their origins as primary and secondary. Primary energy is the energy embodied in natural resources prior to undergoing any human-made conversions or transformations (Kydes, 2007). Primary energy sources are not derived from any other energy source and extracted from nature without any transformation. Also, primary energy sources have an economic value before being processed (Chateau, Lapillonne, 1982). Examples of the primary energy are oil, natural gas, coal and the fuel used in nuclear power. On the other hand, secondary energy is a type of energy that is generated from other energy sources by employing a transformation or conversion process (Bhattacharyya, 2011). The term "other sources" used in the definition of the secondary energy could be primary or secondary sources of energy. Since the secondary sources are derived from primary sources, electricity that is generated by using natural gas, coal or any other primary source, and oil products that are produced with the transformation of oil can be said as the examples of the secondary sources.

There is also another classification of energy sources about their renewability. Renewable energy is an energy that is obtained from the natural sources such as solar, wind and water and that are replenished or regenerated at a faster rate than they are consumed. Also, a nonrenewable energy is a source of energy of which supplies could not be replenished in a short period of time. Their reserves are formed over millions of years (Department of Energy, 2007). More basically, consuming one unit of nonrenewable energy source causes a one-unit decrease in future consumption, since these energy sources cannot regenerate in a short period (Bhattacharyya, 2011). Examples of primary nonrenewable sources are oil, natural gas, and coal. Although the consumption shares of renewable energy sources are increasing with the support of technological changes and growing environmental awareness, the consumption of primary sources still dominates. According to British Petroleum's Statistical Review (2015), total primary energy consumption is $12,928.40$ million tons of oil equivalent whereas total renewable energy consumption including hydroelectricity, solar energy, wind energy geothermal and biomass energy is 1,195.90 million tons of oil equivalent 
GÖRÜŞ, ÖZGÜR | Petrol Talebinin Belirleyicileri: Italya Örneği

in 2014. Thus, primary energy consumption accounts for 91.50 percent of global energy consumption.

Data from the British Petroleum's Statistical Review (2015) show us that oil accounts for 32.57 percent of all primary energy sources in the world in 2014. It is followed by coal and natural gas with shares of 30 and 23.70 percent respectively. Oil is the mostly used energy source, and the relationship between economic growth and oil consumption is positive. However, oil reserves are limited, and only several countries have reserves within their borders that meet their consumption. This concept increases the importance of oil and makes it popular to conduct research about oil consumption.

Economic growth is the main driver of the increase in the welfare of the citizens of the countries. Economic crises disrupt the expansion of total income of nations. The Recent global financial crisis led many countries to experience negative output growth rates. World Bank (2016) data show that the largest five countries with respect to the gross domestic product (GDP) - China, United States, India, Japan, and Germany experienced 10.77, 1.41, 8.95, 0.28 and 0.70 percent average annual GDP growth rates, respectively between 2008 and 2014. It is clear that the growth rates of these spearheading countries are not satisfactory when China and India are excluded.

The economic slowdown is more severe among European Union member countries than other nations. These countries have deeply felt the negative effects of the crisis, and they still live the recovery process. According to World Bank (2016), average growth rate of 27 member countries of the European Union except Malta is -0.13 percent between 2008 and 2014. When it is thought that this ratio is 4.75 percent between 2001 and 2007, it is obvious to say that it is not soon for European Union countries to get rid of devastating effects of the recent global economic crisis. Among the top ten biggest economies of the European Union; Italy, Spain, Netherlands and Romania are the countries that have negative GDP growth rates in real terms between 2008 and 2014. Italy is the one with the highest negative real GDP growth during this period with the rate of -8.08 percent, which corresponds to average -1.35 percent annually.

As it is stated above, Italy is one of the biggest economies of the European Union. Italy was the twelfth largest economy in the world and the fourth largest in Europe on GDP basis in 2014. Furthermore, according to BP Statistical Review (2015), with 148.90 million tons of oil equivalent (MTOE) primary energy consumption. Italy was the fourth largest energy consumer in the European Union in 2014. Currently, it is the fifth biggest oil consumer in the European Union. However, Italy experienced a huge decline in oil consumption between 2008 and 2014. 
These facts make Italian oil market attractive to analyze. There are two main aims of this paper. First, it is aimed at revealing the short run and long run relationships between oil consumption, oil price, and real GDP level. Second, income and price elasticities of oil demand have been calculated in order to give some policy implications about Italian oil market. Italy as an industrialized country needs oil to accelerate production and keep GDP level high. Also, as it is stated, Italy is an oil importer country. Thus, it draws attention to highlight the effect of price and income level over oil consumption for Italy. Therefore, ARDL (Autoregressive Distributed Lag) model is employed to specify the short-run and long-run factors affecting oil consumption in Italy. Given that there is limited research about the price and income elasticities of oil for the Italian economy, it is expected that this paper contributes to the literature.

This paper consists of five parts except for introduction section. In the first part, some basic information is provided about the Italian energy consumption. The second part includes theoretical framework. The relevant literature is reviewed in the third part. Part 4 covers the data used in the study, introduces the econometric methodology, and presents the econometric results. In the final section, general conclusions and policy recommendations are provided.

\section{STRUCTURE OF OVERALL ENERGY CONSUMPTION IN ITALY}

Italy's total primary energy consumption corresponds to 1.15 percent of the total global primary energy consumption. Its share is the seventeenth biggest one in the world, and this value of primary energy consumption corresponds a share of 9.24 percent in the European Union. Italy's total primary energy consumption mainly consists of the consumption of oil, natural gas, and coal. Figure 1 shows us the distribution of these three sources between 1975 and 2014. Moreover, Figure 2 displays sectoral oil consumption in Italy in 2014. 
Figure 1. Trends in primary oil consumption in Italy (1975-2014)

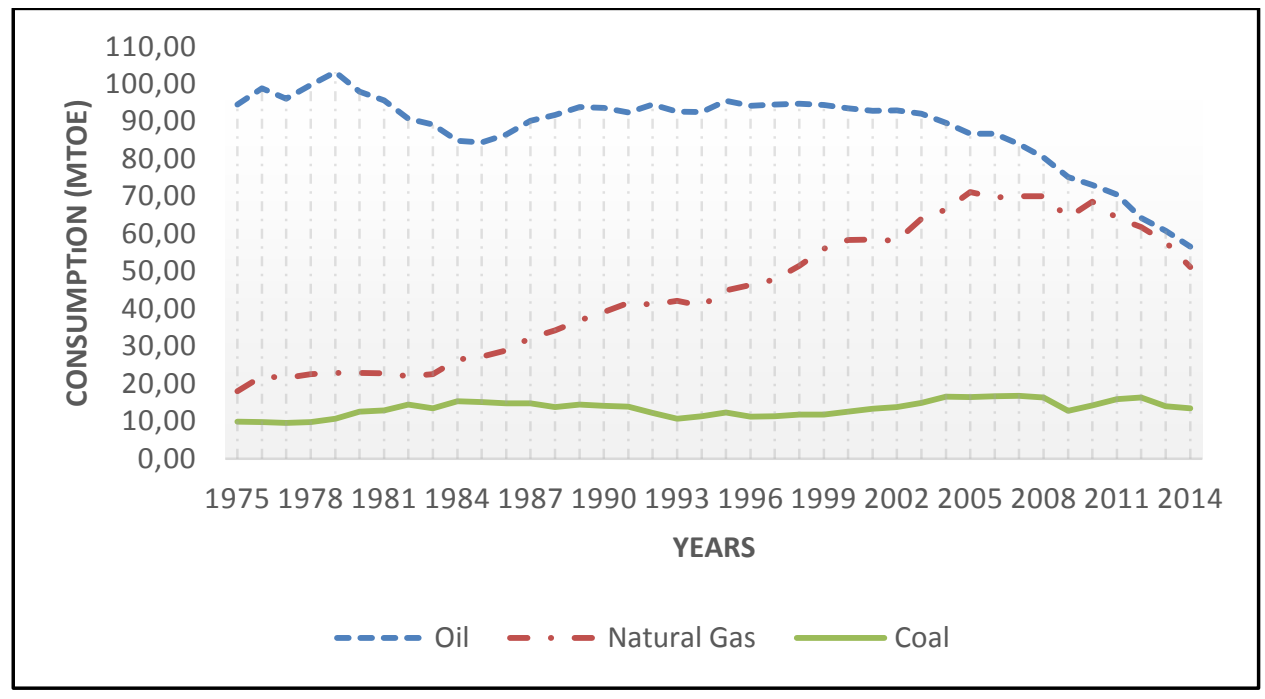

Source: British Petroleum Statistical Review, (2015).

Figure 2. Sectoral oil consumption in Italy (2014)

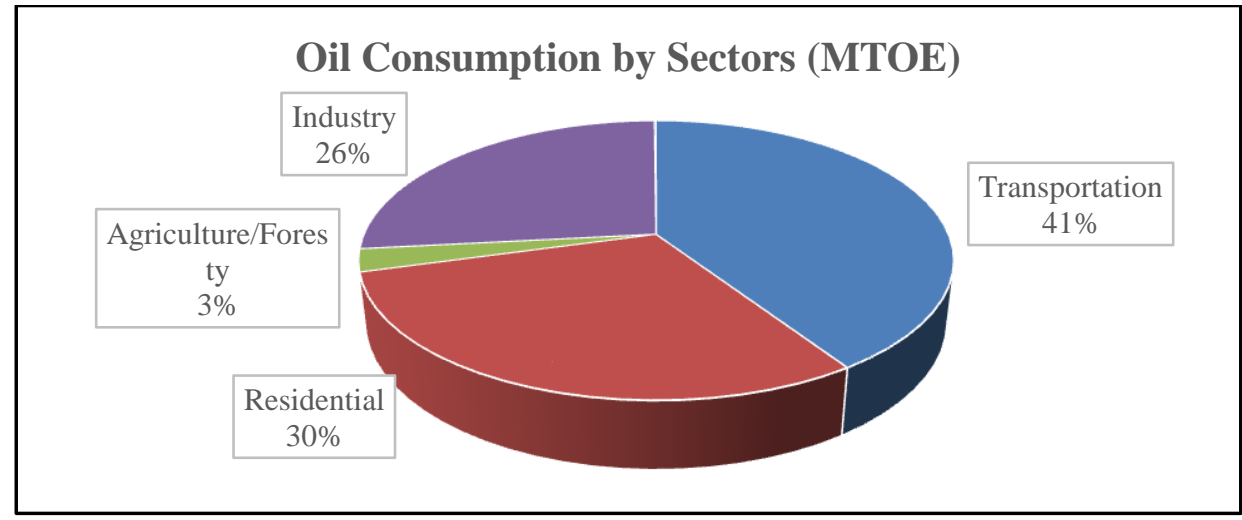

Source: British Petroleum Statistical Review, (2015).

According to Eurostat (2016), Italy's total crude oil production is 5.50 MTOE and 5.87 MTOE in 2013 and 2014 respectively. This production takes place in its 11 refineries which were established in coastal cities due to the convenience of transportation. Italy had 16 refineries when the 2008 economic crisis began. However, it was left with 11 in January 2015 (Villa, 2015). According to production and consumption values, 10.36 percent of total crude oil consumption was met by domestic sources in 2014. Without a doubt, the rest of consumption that is not met domestically must be imported from various sources. Thus, Italy's total oil import was 53.84 MTOE 
in 2014. Although some of them have very smaller volumes, there are 25 countries that Italy imports oil. Azerbaijan, Russia, and Libya are the countries that Italy imports oil with shares in its total imports 22.65 percent, 17.81 percent and 13.06 percent respectively. Also, there is approximately $0.50 \mathrm{MTOE}$ crude oil export of Italy to various countries in 2013.

Briefly, just like many industrialized nations Italy need energy in many sectors and among the most commonly consumed energy sources oil is the one that has the highest share in Italy's consumption. To produce more and accomplish an economic growth Italy needs oil. Given the current state of the Italian energy market, it can also be said that Italy is not a self-sufficient country in oil balance. Therefore, to meet its energy demand Italy has a trade relationship with many countries that has huge oil reserves.

\section{LITERATURE REVIEW}

Energy economics has played a significant role in today's economic and political world. Thus, empirical studies on energy demand have been of particular interest in the literature of economics. Lots of scholars have investigated the relationship especially between energy demand and economic growth with different econometric methods. Summary information about recent studies that are related to energy demand is given in Table 1.

According to Table 1, overall results suggest that there is a cointegration relationship between energy demand and income. Moreover, there is bi-directional and/or unidirectional Granger causality relationship between these variables for different countries and different methods. Empirical results also suggest that price elasticity of energy demand is negative, and income elasticity of energy demand is positive. 
GÖRÜŞ, ÖZGÜR | Petrol Talebinin Belirleyicileri: Italya Örneği

Hacettepe Üniversitesi İktisadi ve İdari Bilimler Fakültesi Dergisi Cilt 35, Sayl 4, 2017

38 
The Determinants of Oil Demand: Evidence from Italy | GÖRÜŞ, ÖZGÜR 


\section{THEORETICAL FRAMEWORK}

In energy economics theory, there are two approaches to analyze the relationship between energy consumption and economic growth. "Supply Side Approach" and "Demand Side Approach" (Bloch et al. 2015).

Supply Side Approach revolves around the production function concept. This approach shows the relationship between energy consumption and economic growth by using the production function that includes energy as an input just like labor, capital or total factor productivity. That is, energy is accepted as one of the main determinants of output growth. $\mathrm{Y}=f(\mathrm{~A}, \mathrm{~K}, \mathrm{~L}, \mathrm{EC})$ where $\mathrm{Y}$ is output growth, $\mathrm{A}$ is total factor productivity, $\mathrm{K}$ is capital, $\mathrm{L}$ is labor and $\mathrm{EC}$ is energy consumption. These models are generally used to reveal the contribution of energy consumption to output growth by taking output growth as a dependent variable and other inputs as independent variables.

Demand Side Approach tries to reveal the impacts of economic parameters on energy consumption. Generally, these types of models take energy as dependent variable and income, own price of the energy source and price of other energy sources as explanatory variables. $\mathrm{EC}=\mathrm{f}(\mathrm{Y}, \mathrm{P}, \mathrm{OP})$ where $\mathrm{EC}$ is energy consumption, $\mathrm{Y}$ is output, $\mathrm{P}$ is the own price of the energy source that is used as dependent variable, OP is the price of other energy sources. This approach is generally used to reveal the contribution of output growth to energy consumption. In this paper, demand-side approach is constructed as oil consumption is dependent variable while the price of oil and per capita real GDP are the independent variables.

Linearly constructed demand side models reveal the relationship between oil consumption and explanatory variables. If the values of the variables are used in their logarithms, the coefficients of the explanatory variables show elasticities. Demand elasticities are commonly derived from the Marshallian demand function that is shown as " $\mathrm{x}\left(\mathrm{P}_{\mathrm{x}}, \mathrm{P}_{\mathrm{y}}, \mathrm{I}\right)$ " where $\mathrm{x}$ is the quantity demanded, $\mathrm{P}_{\mathrm{x}}$ is the own price of a demanded good, $\mathrm{P}_{\mathrm{y}}$ denoted the prices of other goods, and $\mathrm{I}$ is income (Nicholson, Snyder, 2011). In our energy consumption model, Marshallian demand representation of oil demand can be written as "OC (P, Y)" where OC is oil consumption, $\mathrm{P}$ is the price of oil, and $\mathrm{Y}$ is per capita real GDP.

In economic theory, the elasticities show us the responsiveness of quantity demanded of any good to a change in the variables that affect its demand. Price elasticity of demand and income elasticity of demand are two elasticity concepts that are analyzed in this paper. Price elasticity of demand is defined as the proportionate change in quantity demanded for a proportionate change in the price of a good and is shown as $e_{x, p x}$. Since, there is a negative relationship between the price of any good and the 
quantity demanded, the price elasticity of any good takes negative values. If the value is between 0 and -1 , the price elasticity of any good is called as inelastic, and if it is smaller than -1 , it is named as elastic. Furthermore, the income elasticity of demand is defined as the proportionate change in the quantity demanded for a proportionate change in income and is shown as $e_{x, I}$. If the amount demanded of any good increases when income rises, this good is said to be a normal good and, if the amount demanded of any good decreases when income increases, the good is known as an inferior good. Briefly, the good is normal when the income elasticity takes positive values and an inferior good if the income elasticity is negative. Indeed, by using the logarithmic values of oil consumption, the price of oil and per capita real GDP, this paper aims at revealing the value of a percentage change in the quantity of oil consumption in Italy with respect to the percentage change in oil price and GDP both in the short run and in the long-term.

\section{DATA AND METHODOLOGY}

\subsection{Data}

This article is based on the demand side approach which is derived from the Marshallian demand theory for goods and services. According to this theory, the model includes crude oil consumption per capita (in terms of daily thousand barrels), LOC, as the dependent variable, crude oil prices (in terms of 2005 U.S. dollars), LP, and real Gross Domestic Product (GDP) per capita (in terms of 2005 U.S. dollars), LY, as the independent variables. All variables are expressed in logarithmic form. This analysis is based on annual time series data covering the period of 1975-2014 for Italy. The data for total crude oil consumption and nominal crude oil prices are gathered from BP Statistical Review of World Energy (2015). Also, GDP per capita, GDP deflator, and population data are collected from World Bank (2015). Population data were used to calculate crude oil consumption per capita while GDP deflator data were used to deflate nominal oil prices. Time series data of variables in logarithmic form are displayed in Figure 3. Furthermore, Table 2 gives the summary statistics of each main variable that is used in the analysis. 
Figure 3. Time Series Data of Variables in Logarithmic Form

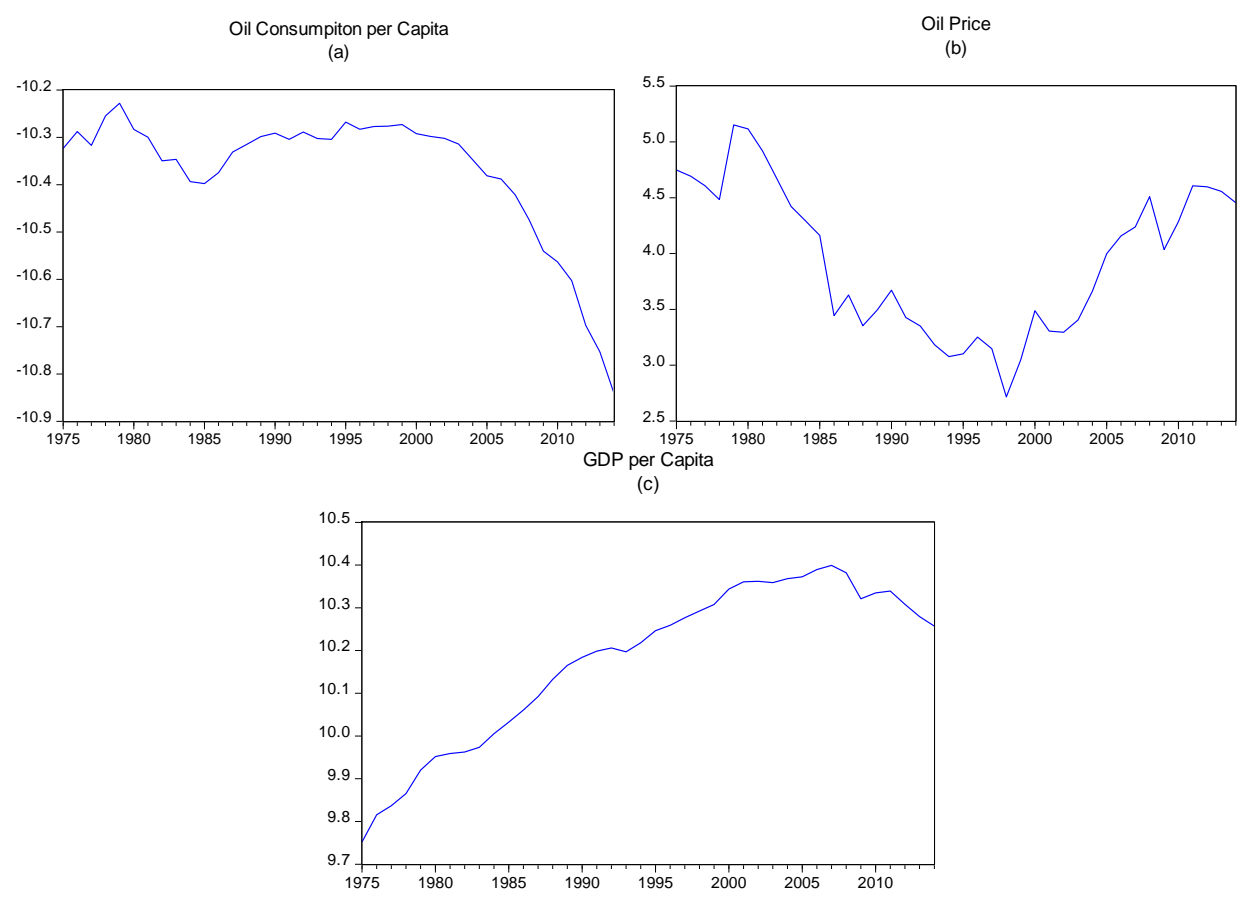

According to Figure 3, oil consumption per capita has started to decrease since the beginnings of the 2000s in part (a). Substitution of crude oil with natural gas leads to decrease in oil consumption as shown in Figure 1. Moreover, because of oil is being input in production processes, decline in oil consumption per capita after 2008 global financial crisis might be due to economic slowdown of the Italian economy. So, negative economic growth affects oil consumption, negatively. Also, demand for crude oil could be affected by an increase in other alternative energy sources' usage. In part (b), oil prices had faced sharp increases and decreases in this period because of change in demand and supply side of crude oil and other political issues. High oil prices from 1975 to 1980 are affected by 1973 and 1979 World Oil Crises. In addition, increase in oil prices from the beginning of the 2000s might be affected by high tension in the Middle East, high demand of Chinese economy, and falling value of the U.S. dollar. On the other hand, GDP per capita has an increasing trend about until the mid of the 2000s in part (c), and it has affected negatively especially by the 2008 world economic crisis. 
Table 2. Descriptive Statistics of the Variables

\begin{tabular}{lcccccc}
\hline Descriptive Statistics & $\mathbf{L O C}$ & $\mathbf{L P}$ & $\mathbf{L Y}$ & $\Delta \mathbf{L O C}$ & $\Delta \mathbf{L P}$ & $\Delta \mathbf{L Y}$ \\
\hline Mean & -10.37 & 3.94 & 10.17 & -0.01 & -0.00 & 0.01 \\
Median & -10.31 & 4.01 & 10.23 & -0.01 & -0.04 & 0.01 \\
Maximum & -10.22 & 5.15 & 10.39 & 0.06 & 0.66 & 0.06 \\
Minimum & -10.84 & 2.71 & 9.75 & -0.09 & -0.71 & -0.06 \\
Standard Deviation & 0.14 & 0.66 & 0.18 & 0.03 & 0.26 & 0.02 \\
Skewness & -1.89 & 0.06 & -0.70 & -0.19 & -0.03 & -0.69 \\
Kurtosis & 5.88 & 1.73 & 2.26 & 2.72 & 3.52 & 4.16 \\
\hline
\end{tabular}

Note: $\Delta$ is the difference operator.

\subsection{Methodology}

In this paper, a cointegration relationship between variables is estimated by ARDL model. Then, the long run equation and Error Correction Model (ECM) were established to find the long run and short run elasticities of oil demand in Italy for the period of 1975-2014.

The Bound Test was developed by Pesaran et al. (2001). This test is based on ARDL model. There are several advantages of this method. The Bound Test could be employed with $\mathrm{I}(0)$ or $\mathrm{I}(1)$ data. Moreover, it could be implemented with a mixture of $\mathrm{I}(0)$ and $\mathrm{I}(1)$ data. Also, it solves the endogeneity problem - an explanatory variable is correlated with the error term - in the model. It provides consistent results for the even small sample. Lastly, unrestricted error correction model results can easily integrate the short run dynamics with the long run equilibrium without losing any long run information (Bloch et al., 2015:108). Furthermore, ARDL model has some advantages over other tests like Johansen cointegration technique. First, it allows constructing a model covering the variables in which some of them are stationary at level, and the others are stationary at first difference (Pesaran et al., 2001). Conversely, Johansen cointegration method requires all included variables to be stationary at first difference. Second, all variables in the model are assumed to be endogenous. Third, short-run and long-run coefficients could be estimated continuously (Dritsakis, 2011). On the other side, there are a few downsides of this method. First, it includes more steps in comparison to other cointegration tests. Second, I(2) and higher degrees of data are not allowed to be in the model. Thirdly, it is based on the assumption of the existence of one cointegration vector (Dergiades and Tsoulfidis, 2008). According to its advantages, Bound Test is constructed as a more suitable tool to represent both short-run and longrun relationship between oil consumption and price and GDP level. To find cointegration relationship between variables, an ARDL model is constructed as follows: 


$$
\begin{aligned}
& \Delta L O C_{t}=\alpha+\sum_{i=1}^{m} \beta_{1 i} \Delta L O C_{t-i}+\sum_{i=0}^{m} \beta_{2 i} \Delta L P_{t-i}+\sum_{i=0}^{m} \beta_{3 i} \Delta L Y_{t-i}+\beta_{4} L O C_{t-1}+ \\
& \beta_{5} L P_{t-1}+\beta_{6} L Y_{t-1}+\varepsilon_{t}
\end{aligned}
$$

where $\Delta$ is the difference operator, $\alpha$ is the intercept term, $\beta$ 's are the coefficients of variables, and $\varepsilon$ is the error term. The ARDL model estimates the above equation to obtain the optimal lag length for each dependent and independent variable. Lag selection is based on minimum Akaike Information Criterion (AIC) which has no autocorrelation problem. Then, the following hypotheses should be tested to determine the existence of a cointegration relationship between variables. The null hypothesis of no cointegration $\left(\mathrm{H}_{0}: \beta_{4}=\beta_{5}=\beta_{6}=0\right)$ is tested against the alternative of cointegration $\left(\mathrm{H}_{1}: \beta_{4} \neq \beta_{5} \neq \beta_{6} \neq 0\right)$. The series are cointegrated if the calculated F-statistics is larger than upper critical bound (I(1)), and not cointegrated, if the calculated F-statistics is smaller than lower critical bound (I(0)) of Pesaran et al. (2001). If the calculated Fstatistics falls between $\mathrm{I}(0)$ and $\mathrm{I}(1)$ as bounds, the inference is uncertain.

If the variables are cointegrated according to the Bound Test result, long run and short run error correction models are established as in Equation 2 and Equation 3, respectively. ECT refers to Error Correction Term of the ECM. It is gathered from the long run equation residuals. $\lambda$ denotes the coefficient of the ECT. These equations are used to find the price and income elasticities of oil demand both in the short run and in the long-term.

$$
\begin{aligned}
& L O C_{t}=\alpha+\sum_{i=1}^{m} \beta_{1 i} L O C_{t-i}+\sum_{i=0}^{n} \beta_{2 i} \Delta L P_{t-i}+\sum_{i=0}^{p} \beta_{3 i} L Y_{t-i}+\varepsilon_{t} \\
& \Delta L O C_{t}=\alpha+\sum_{i=1}^{m} \beta_{1 i} \Delta L O C_{t-i}+\sum_{i=0}^{n} \beta_{2 i} \Delta L P_{t-i}+\sum_{i=0}^{p} \beta_{3 i} L Y_{t-i}+\lambda E C T_{t-1}+\varepsilon_{t}
\end{aligned}
$$

\subsection{Empirical Findings}

In time series analysis, the stationarity of the variables is very significant to estimate an econometric model. If the series have a unit root, one may face the spurious relationship in the model (Granger, Newbold, 1974). Therefore, we use the Augmented Dickey-Fuller (ADF) test and the Phillips-Perron (PP) test for conducting the unit root tests. The ADF and the PP test the null hypothesis of non-stationarity. Unit root test results of the variables are presented in Table 3. Moreover, unit root tests with structural breaks are currently used prominent methods in unit root analyses. We use Lee and Strazicich (2004) LM unit root test with one-break and Lee and Strazicich (2003) LM unit root test with two-break in this study. Unit root tests with structural break(s) for break in level model and break in level and trend model results are displayed in Table 4 and Table 5. 
Table 3. Results for the ADF and PP Unit Root Tests

\begin{tabular}{|c|c|c|c|c|}
\hline \multirow[b]{2}{*}{ Variables } & \multicolumn{2}{|c|}{ ADF Test } & \multicolumn{2}{|c|}{ PP Test } \\
\hline & Constant & $\begin{array}{l}\text { Constant \& } \\
\text { Trend }\end{array}$ & Constant & $\begin{array}{l}\text { Constant \& } \\
\text { Trend }\end{array}$ \\
\hline LOC & 4.09 & 2.04 & 3.53 & 1.88 \\
\hline LP & -1.43 & -1.09 & -1.43 & -1.09 \\
\hline LY & -2.27 & 0.85 & $-3.87 * * *$ & 1.22 \\
\hline$\Delta \mathrm{LOC}$ & $-3.63 * * *$ & $-4.71 * * *$ & $-3.70 * * *$ & $-4.86 * * *$ \\
\hline$\Delta \mathbf{L P}$ & $-6.06 * * *$ & $-6.32 * * *$ & $-6.06 * * *$ & $-6.36 * * *$ \\
\hline$\Delta \mathbf{L Y}$ & $-3.51 * *$ & $-4.93 * * *$ & $-3.46 * *$ & $-4.91 * * *$ \\
\hline
\end{tabular}

Note: $\Delta$ is the first difference operator. $* * *$ and $* *$ denote statistical significance at the $1 \%$ and $5 \%$ level, respectively.

Table 4. Results of Lee and Strazicich (2004) LM Unit Root Test with One-Break

\begin{tabular}{|c|c|c|c|c|c|c|}
\hline \multirow[b]{2}{*}{ Variables } & \multicolumn{3}{|c|}{ Break in Level } & \multicolumn{3}{|c|}{$\begin{array}{c}\text { Break in } \\
\text { Level and Trend }\end{array}$} \\
\hline & Test Stat & $\begin{array}{l}\text { Break } \\
\text { Point } \\
\end{array}$ & Break Date & Test Stat & $\begin{array}{c}\text { Break } \\
\text { Point } \\
\end{array}$ & Break Date \\
\hline LOC & $-3.70 * *$ & 14 & 1988 & $-4.61 * *$ & $26(\lambda: 0.65)$ & 2000 \\
\hline $\mathbf{L P}$ & -2.43 & 15 & 1989 & -4.12 & $23(\lambda: 0.57)$ & 1997 \\
\hline LY & -1.30 & 13 & 1987 & -2.99 & $15(\lambda: 0.37)$ & 1989 \\
\hline$\Delta \mathbf{L P}$ & $-6.23 * * *$ & 24 & 1999 & $-6.30 * * *$ & $29(\lambda: 0.74)$ & 2004 \\
\hline$\Delta \mathbf{L Y}$ & $-4.96 * * *$ & 24 & 1999 & $-5.44 * * *$ & $18(\lambda: 0.46)$ & 1993 \\
\hline
\end{tabular}

Note: $\Delta$ is the first difference operator. $* * *$ and $* *$ denote statistical significance at the $1 \%$ and $5 \%$ level, respectively. $\lambda\left(\lambda=\mathrm{T}_{\text {break }} / \mathrm{T}\right)$ denotes the location of the break.

Table 5. Results of Lee and Strazicich (2003) LM Unit Root Test with Two-Break

\begin{tabular}{lcccccc}
\hline & \multicolumn{3}{c}{ Break in Level } & \multicolumn{3}{c}{$\begin{array}{c}\text { Break in } \\
\text { Level and Trend }\end{array}$} \\
\cline { 2 - 7 } Variables & Test Stat & $\begin{array}{c}\text { Break } \\
\text { Points }\end{array}$ & $\begin{array}{c}\text { Break } \\
\text { Dates }\end{array}$ & Test Stat & $\begin{array}{c}\text { Break } \\
\text { Points }\end{array}$ & $\begin{array}{c}\text { Break } \\
\text { Dates }\end{array}$ \\
\hline LOC & $-4.15^{* *}$ & 13 & 1987 & $-6.38 * *$ & $14\left(\lambda_{1}: 0.35\right)$ & 1988 \\
& & 33 & 2007 & & $25\left(\lambda_{2}: 0.62\right)$ & 1999 \\
$\mathbf{L P}$ & -2.67 & 20 & 1994 & -5.25 & $25\left(\lambda_{1}: 0.62\right)$ & 1999 \\
& & 23 & 1997 & & $30\left(\lambda_{2}: 0.75\right)$ & 2004 \\
$\mathbf{L Y}$ & -1.53 & 13 & 1987 & -5.58 & $13\left(\lambda_{1}: 0.32\right)$ & 1987 \\
& & 31 & 2005 & & $30\left(\lambda_{2}: 0.75\right)$ & 2004 \\
$\Delta \mathbf{L P}$ & $-6.74 * * *$ & 24 & 1999 & $-7.27 * * *$ & $12\left(\lambda_{1}: 0.30\right)$ & 1987 \\
& & 36 & 2011 & & $32\left(\lambda_{2}: 0.82\right)$ & 2007 \\
$\Delta \mathbf{L Y}$ & $-5.87 * * *$ & 19 & 1994 & $-6.07 * *$ & $17\left(\lambda_{1}: 0.43\right)$ & 1992 \\
& & 21 & 1996 & & $22\left(\lambda_{2}: 0.56\right)$ & 1997 \\
\hline
\end{tabular}

Note: $\Delta$ is the first difference operator. $* * *$ and $* *$ denote statistical significance at the $1 \%$ and $5 \%$ level, respectively. $\lambda_{\mathrm{j}}\left(\lambda=\mathrm{T}_{\text {break }} / \mathrm{T}\right)$ denotes the location of the breaks. 
According to the ADF and PP unit root test results, LOC, LP, and LY are stationary at first difference (I(1)) for models which include both constant and constant and trend. On the other hand, Lee and Strazicich (2004, 2003) tests reveal that LOC is stationary at level $(\mathrm{I}(0))$ for both models while LP and LY are stationary at first difference (I(1)) for both models. So, we cannot employ Engle-Granger (1987), Johansen (1988), and Johansen and Juselius (1990) cointegration tests. Since there is no I(2) data, we can apply the Bound Test. Lag length results for Equation 1 are presented in Table 6. In the empirical literature, maximum lag length is taken between 2 and 4 for annual data, generally. Maximum 4 lag is used to find the cointegration relationship between variables because our dataset is relatively large, 40 observations, for yearly data. AIC is used to determine the optimal lag length for the ARDL model.

Table 6. Optimal Lag Length(s)

\begin{tabular}{cccc}
\hline Lags & AIC & LM $_{(\mathbf{S C})}$ & F-stat \\
\hline 1 & -4.69 & 0.90 & 4.40 \\
2 & -4.61 & 0.40 & 2.40 \\
3 & -4.82 & 0.14 & 3.68 \\
$4^{*}$ & -4.97 & 0.87 & 4.87 \\
\hline
\end{tabular}

Note: $\mathrm{LM}_{(\mathrm{SC})}$ is the probability value of Breusch-Godfrey Lagrange Multiplier test results. * shows the optimal lag length which has no autocorrelation problem.

ARDL $(4,4,4)$ is the optimal model for the cointegration analysis. Moreover, there is no autocorrelation problem in this estimated model. According to the Bound Test result, calculated F-statistics of the model is found to be 4.87 . This value should be compared against the critical values of Pesaran et al. (2001) for unrestricted constant and no trend model. F-statistics for cointegration exceeds upper critical bounds for two independent variables of Pesaran et al. (2001) at 10\% and 5\% significance levels. Upper critical values of Pesaran et al. (2001) are 4.14 and 4.85, respectively. Thus, empirical results show that there is a long-run cointegration relationship between oil demand, oil prices, and GDP.

Since we have found cointegration relationship between variables, we need to set up the long run model in Equation 2. $(4,2,4)$ are the optimal lags for the long term model and its estimation results are showed in Table 7. There is no autocorrelation, heteroscedasticity and normality problem in the long term estimation. 
Table 7. Coefficients for Long Run Model

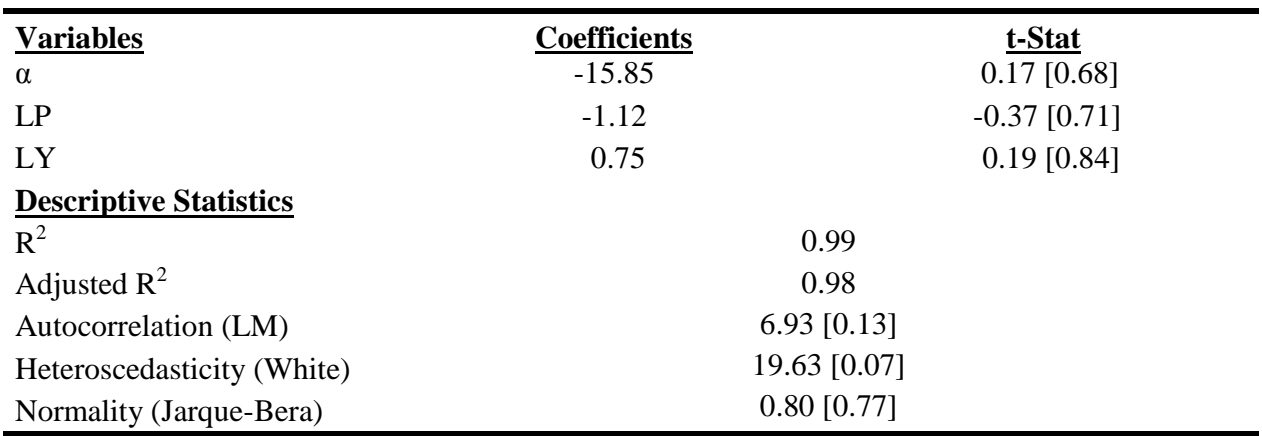

Note: Figures in the square brackets are p-values. Long-run elasticities are calculated by the sum of the coefficients of each independent variable that is divided by subtraction of the sum of the coefficients of the dependent variable's lags from 1.

The price and income elasticity of oil demand are calculated as -1.12 and 0.75 respectively. However, both price and income elasticities are found to be statistically insignificant. CUSUM and CUSUMQ tests are used to test the constancy of the coefficients in a model. The test results are displayed in Figure 4. Both the CUSUM and CUSUM of Squares (CUSUMQ) fall within the lines. Thus, the long run model is effective with stable recursive residuals.

Figure 4. CUSUM and CUSUMQ of long Run Model
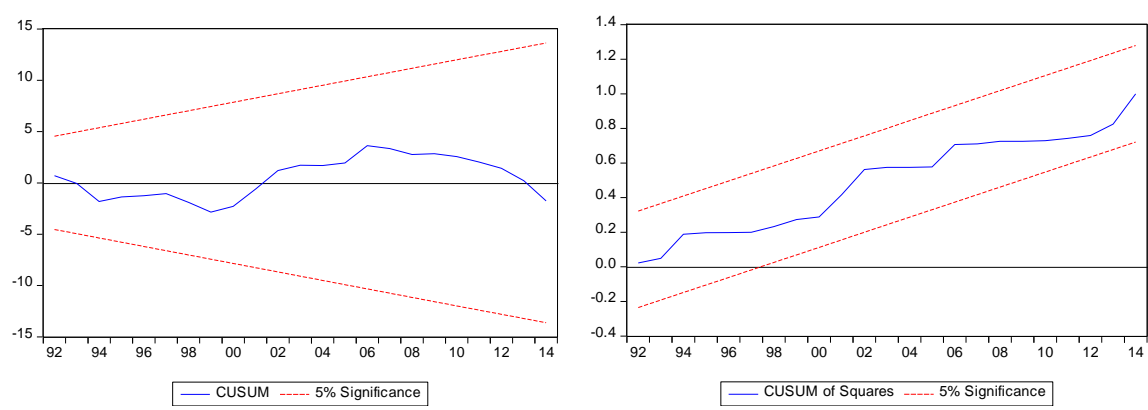

We set up ECM like in Equation 3. after getting long term results. $(1,4,4)$ are the optimal lag lengths of the ECM and its estimation results are displayed in Table 8. There is also no autocorrelation, heteroscedasticity or normality problem in the short run estimation.

According to the results, one lagged value of oil demand affects oil demand positively, 0.78 , in the current year. Moreover, one lagged value of oil prices, -0.03 , affect oil demand, negatively. On the other hand, the income elasticity of oil demand is estimated to be 0.65 . The equilibrium error correction coefficient ECT(-1) is -1.18 , 
GÖRÜŞ, ÖZGÜR | Petrol Talebinin Belirleyicileri: Italya Örneği

which is negative and significant as expected. Therefore, a deviation from the long-run equilibrium level of oil demand is corrected about one year later. The speed of adjustment is very high in the Italian oil market. CUSUM and CUSUMQ test results are shown in Figure 5. Both the CUSUM and CUSUMQ of Squares fall within the lines. Thus, the Error Correction Model is effective with stable recursive residuals too.

Table 8. ECM Estimation Results

\begin{tabular}{|c|c|c|}
\hline Variables & $\underline{\text { Coefficients }}$ & $\underline{\text { t-Stat }}$ \\
\hline $\bar{\alpha}$ & -0.00 & $-0 . \overline{39[0.69]}$ \\
\hline$\Delta \mathrm{LOC}(-1)$ & $0.78 * * *$ & $3.05[0.00]$ \\
\hline$\Delta \mathrm{LP}$ & -0.01 & $-0.88[0.38]$ \\
\hline$\Delta \mathrm{LP}(-1)$ & $-0.03 * * *$ & $-2.82[0.00]$ \\
\hline$\Delta \mathrm{LP}(-2)$ & 0.02 & $1.65[0.11]$ \\
\hline$\Delta \mathrm{LP}(-3)$ & -0.01 & $-0.70[0.48]$ \\
\hline$\Delta \mathrm{LP}(-4)$ & -0.00 & $-0.21[0.83]$ \\
\hline$\Delta \mathrm{LY}$ & $0.65 * *$ & $2.49[0.02]$ \\
\hline$\Delta \mathrm{LY}(-1)$ & -0.15 & $-0.52[0.60]$ \\
\hline$\Delta \mathrm{LY}(-2)$ & -0.32 & $-1.29[0.20]$ \\
\hline$\Delta \mathrm{LY}(-3)$ & 0.38 & $1.45[0.15]$ \\
\hline$\Delta \mathrm{LY}(-4)$ & -0.46 & $-2.01[0.05]$ \\
\hline ECT(-1) & $-1.18 * * *$ & $-3.52[0.00]$ \\
\hline \multicolumn{3}{|l|}{ Descriptive Statistics } \\
\hline $\mathrm{R}^{2}$ & \multicolumn{2}{|c|}{0.79} \\
\hline Adjusted $\mathrm{R}^{2}$ & \multicolumn{2}{|c|}{0.67} \\
\hline Autocorrelation (LM) & \multicolumn{2}{|c|}{$5.65[0.22]$} \\
\hline Heteroscedasticity (White) & \multicolumn{2}{|c|}{3.49 [0.99] } \\
\hline Normality (Jarque-Bera) & \multicolumn{2}{|c|}{$2.40[0.30]$} \\
\hline
\end{tabular}

Note: $* * *$ and $* *$ denote statistical significance at the $1 \%$ level and $5 \%$ level, respectively. Figures in the square brackets are p-values.

Figure 5. CUSUM and CUSUMQ of ECM
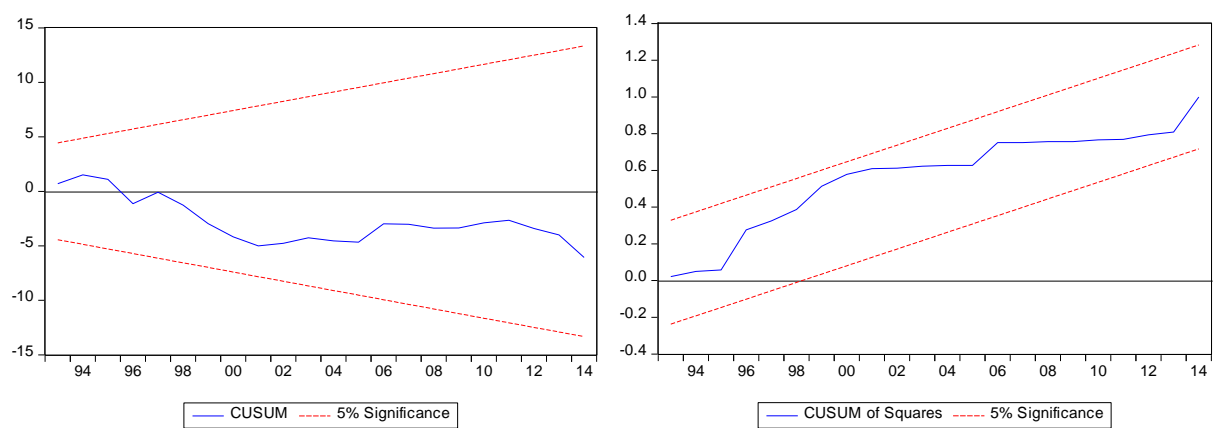

Hacettepe Üniversitesi İktisadi ve İdari Bilimler Fakültesi Dergisi | Cilt 35, Sayl 4, 2017

48 
In the short-term perspective, our results are similar to the findings by Cooper (2003), Altinay (2007), and Kim and Baek (2013). Cooper (2003) estimated the price elasticity of crude oil for 23 countries. Altinay (2007) and Kim and Baek (2013) estimated price and income elasticities of oil demand in Turkey and South Korea, respectively. Almost all of these are oil dependent countries, and they have limited oil reserves like Italy.

\section{CONCLUSION}

In this paper, ARDL model is employed to estimate price and income elasticity of oil demand for Italy both in the short run and in the long run, by using annual time series data that covers the period between 1975 and 2014. Empirical results show that oil demand, oil prices, and income have a cointegration relationship in the long run. Long-run results suggest that the income elasticity of oil demand is found to be 0.75 . It is positive as expected and elastic. On the other side, the price elasticity of oil demand is estimated to be -1.12. However, both coefficients are statistically insignificant in the long run. ECM results show that the short run one lagged price and income elasticities of oil demand for Italy are -0.03 and 0.65 , respectively. They are statistically significant and have theoretically correct signs as expected. It is also seen that compared to oil prices, income is a more powerful determinant of oil demand. Moreover, the ECT is found to be -1.18 which is between 0 and -2 , as indicated by the ECT theory. It means that a deviation from the long-run equilibrium level of oil demand in Italy is corrected about one year later. All the estimated models above pass the diagnostic tests successfully. The econometric results suggest that oil is a necessity good and normal good for Italian consumers.

In this study, the income elasticity of oil demand is found to be positive-inelastic, 0.65 , in the short run. On the other side, the one lagged price elasticity of oil demand is calculated to be negative-inelastic, -0.03 , in the short run. It means that oil demands of consumers are more sensitive to changes in income rather than changes in price in the near term.

Negative and very low price elasticity in the short run means that Italian economy depends heavily on crude oil. Since Italy lacks oil reserves, it is regarded as an oil dependent and oil importer country. These facts make Italy vulnerable to shocks in oil prices. Italy needs to reduce its oil dependency by introducing alternative energy resources such as natural gas, hydroelectricity, solar energy, wind energy, biomass energy, and nuclear energy. Also, curbing oil demand or increasing energy efficiency will help decrease oil dependency of the country. 
GÖRÜŞ, ÖZGÜR | Petrol Talebinin Belirleyicileri: Italya Örneği

\section{REFERENCES}

Altinay, G. (2007), "Short-Run and Long-Run Elasticities of Import Demand for Crude Oil in Turkey”, Energy Policy, 35(11), 5829-5835.

Behmiri, N.B., J.R.P. Manso (2013), "How Crude Oil Consumption Impacts on Economic Growth of Sub-Saharan Africa?", Energy, 54, 74-83.

Bhattacharyya, S.C. (2011), Energy Economics: Concepts, Issues, Markets and Governance, Springer Science \& Business Media.

Bildirici, M.E., T. Bakirtas (2014), "The Relationship Among Oil, Natural Gas and Coal Consumption and Economic Growth in BRICTS (Brazil, Russia, India, China, Turkey and South Africa) Countries”, Energy, 65, 134-144.

Bloch, H., S. Rafiq, R. Salim (2015), "Economic Growth with Coal, Oil and Renewable Energy Consumption in China: Prospects for Fuel Substitution”, Economic Modelling, 44, 104 115.

British Petroleum (2015), Historical Data Workbook. BP Statistical Review of World Energy 2015, http://www.bp.com (Accessed March 11, 2016)

Chateau, B., B. Lapillonne (1982), Energy Demand in The Residential and Tertiary Sector, In Energy Demand: Facts and Trends. Springer Vienna.

Cooper, J.C. (2003), "Price Elasticity of Demand for Crude Oil: Estimates for 23 Countries", OPEC Review, 27(1), 1-8.

Department of Energy (2007), Energy Efficiency and Renewable Energy. Secondary Energy Infobook.

Dergiades, T., L. Tsoulfidis (2008), "Estimating Residential Demand for Electricity in the United States, 1965-2006”, Energy Economics, 30(5), 2722-2730.

Dritsakis, N. (2011), "Demand for Money in Hungary: An ARDL Approach", Review of Economics and Finance, 5, 1-28.

Engle, R.F., C.W. Granger (1987), "Co-Integration and Error Correction: Representation, Estimation, and Testing”, Econometrica: Journal of The Econometric Society, 55(2), 251-276.

Erdal, G., H. Erdal, K. Esengün (2008), "The Causality Between Energy Consumption and Economic Growth in Turkey”, Energy Policy, 36(10), 3838-3842.

Eurostat (2016), Energy Statistics, Http://Ec.Europa.Eu/Eurostat/Web/Energy/Data/Database (Accessed April 4, 2016)

Fuinhas, J.A., A.C. Marques (2012), "Energy Consumption and Economic Growth Nexus in Portugal, Italy, Greece, Spain and Turkey: An ARDL Bounds Test Approach (19652009)", Energy Economics, 34(2), 511-517.

Ghosh, S. (2009), "Import Demand of Crude Oil and Economic Growth: Evidence from India", Energy Policy, 37(2), 699-702.

Granger, C.W., P. Newbold (1974), "Spurious Regressions in Econometrics", Journal of Econometrics, 2(2), 111-120.

Hacettepe Üniversitesi İktisadi ve İdari Bilimler Fakültesi Dergisi |

Cilt 35, Sayl 4, 2017

50 
Johansen, S. (1988), "Statistical Analysis of Cointegration Vectors", Journal of Economic Dynamics and Control, 12(2), 231-254.

Johansen, S., Juselius, K. (1990), "Maximum Likelihood Estimation and Inference on Cointegration-With Applications to the Demand for Money", Oxford Bulletin of Economics and Statistics, 52(2), 169-210.

Kim, H.S., Baek, J. (2013), “Assessing Dynamics of Crude Oil Import Demand in Korea", Economic Modelling, 35, 260-263.

Kydes, A. (2007), Primary Energy. Http://www.Eoearth.Org/View/Article/155350/ (Accessed April 4, 2016).

Lee, J., Strazicich, M.C. (2003), "Minimum Lagrange Multiplier Unit Root Test with Two Structural Breaks", Review of Economics and Statistics, 85(4), 1082-1089.

Lee, J., Strazicich, M.C. (2004), "Minimum LM Unit Root Test with One Structural Break", Manuscript, Department of Economics, Appalachian State University, 1-16.

Magazzino, C. (2014), "The Relationship Between CO2 Emissions, Energy Consumption and Economic Growth in Italy", International Journal of Sustainable Energy, 1-14.

Magazzino, C. (2015), "Energy Consumption and GDP in Italy: Cointegration and Causality Analysis", Environment, Development and Sustainability, 17(1), 137-153.

Narayan, P.K., Smyth, R. (2008), "Energy Consumption and Real GDP in G7 Countries: New Evidence from Panel Cointegration with Structural Breaks", Energy Economics, 30(5), 2331-2341.

Nicholson, W., Snyder, C. (2011), Microeconomic Theory: Basic Principles and Extensions, Nelson Education.

Omri, A. (2013), " $\mathrm{CO}_{2}$ Emissions, Energy Consumption and Economic Growth Nexus in MENA Countries: Evidence from Simultaneous Equations Models”, Energy Economics, 40, 657-664.

Ouedraogo, N.S. (2013), "Energy Consumption and Economic Growth: Evidence from The Economic Community of West African States (ECOWAS)", Energy Economics, 36, 637-647.

Pesaran, M.H., Shin, Y., Smith, R.J. (2001), "Bounds Testing Approaches to the Analysis of Level Relationships", Journal of Applied Econometrics, 16(3), 289-326.

Saboori, B., Sulaiman, J. (2013), " $\mathrm{CO}_{2}$ Emissions, Energy Consumption and Economic Growth in Association of Southeast Asian Nations (ASEAN) Countries: A Cointegration Approach.", Energy, 55, 813-822.

Villa, M. (2015), 2014 In Refining: Europe is Ailing, Italy is Worse, Http://Www.Ispionline.It/En/Energy-Watch/2014-Refining-Europe-Ailing-Italy-Worse12018 (Accessed March 17, 2016).

World Bank (2016), Http://Data.Worldbank.Org/ (Accessed March 11, 2016).

Ziramba, E. (2010), "Price and Income Elasticities of Crude Oil Import Demand in South Africa: A Cointegration Analysis", Energy Policy, 38(12), 7844-7849. 